\title{
Benefit-cost analysis of Rhode Island Red chicken rearing in backyard on the basis of egg production performance
}

\author{
P. K. Das ${ }^{1}$, P. R. Ghosh ${ }^{1}$, S. Pradhan ${ }^{2}$, B. Roy ${ }^{3}$ and D. Mazumdar ${ }^{4}$
}

1. Department of Veterinary Physiology, West Bengal University of Animal \& Fishery Sciences,

37, K. B. Sarani, Kolkata - 700 037, West Bengal, India; 2. Department of Veterinary Pathology, West Bengal University of Animal \& Fishery Sciences, 37, K. B. Sarani, Kolkata - 700 037, West Bengal, India; 3. Department of Animal Nutrition, West Bengal University of Animal \& Fishery Sciences, 37, K. B. Sarani, Kolkata - 700 037, West Bengal, India; 4. Department of Agriculture Statistics, Bidhan Chandra Krishi Viswavidyalaya, West Bengal, India.

Corresponding author: P. K. Das, email: pkdaskol@rediffmail.com

PRG: drprghosh@gmail.com, SP: saktipadapradhan@gmail.com, BR: barunnutrition@yahoo.co.in, DM: debstat@gmail.com Received: 29-04-2014, Revised: 01-07-2014, Accepted: 07-07-2014, Published online: 16-08-2014

doi: 10.14202/vetworld.2014.605-609

How to cite this article: Das PK, Ghosh PR, Pradhan S, Roy B and Mazumdar D (2014) Benefit cost analysis of Rhode Island Red chicken rearing in backyard on the basis of egg production performance, Veterinary World 7(8): 605-609.

\begin{abstract}
Aim: The aim of the present study was to analyze of the egg production features of backyard chicken rearing with an evaluation of production cost of an egg and there by benefit-cost analysis.

Materials and Methods: Study was conducted on 60000 chicken covering five different agroclimatic zones in the state West Bengal, India. Initially each farmer was provided day-old Rhode Island Red chicks, commercial ration upto pre-laying stage having CP of $17.23 \%$ and $12.32 \%$ in chick and grower mash respectively along with common management support system for backyard poultry rearing viz. separate poultry night shelter and brooding facilities, deworming and vaccination and regular health check up system, later farmers were allowed to use the supplemented feed made by the locally available resources having various crude protein content.

Results: It was observed that there was no significant variation in respect of total egg production under various supplemented crude protein containing feed, whereas significantly higher egg production feature is observed in Coastal and Old Alluvial zones.

Conclusion: The study concluded that more profit was occurred to those farmers who provided the supplemented feed with less crude protein content along with scavenging. This scope is more in new alluvial zone. It was also observed that profit started from 11 month onwards in each agro-climatic zone as well as in each category of supplemented feed.
\end{abstract}

Keywords: backyard, benefit-cost analysis, chicken, egg production, RIR.

\section{Introduction}

About $85 \%$ of chicken stock of India belongs to small sector which provides $50 \%$ of total egg production [1-3]. Family chicken through the International Network on Family Poultry Development (INFPD) was also committed by the Food and Agriculture Organization (FAO) as a Special Programme for Food Security (SPFS) in the developing countries including India where backyard chicken production system has been encouraged [4]. Rural farmers were motivated for backyard chicken production under the largest Poultry Distribution Scheme of world in the West Bengal state [5]. But, basic data related to egg production performance and benefit-cost analysis of the distributing chickens, the Rhode Island Red (RIR), at the backyard was not standardized.

On this background, an attempt was made to standardize the basic egg production data in respect to backyard chicken rearing at various agro-climatic zones of West Bengal viz. age of maturity, weekly hen day, laying period, total egg production. These egg

Copyright: The authors. This article is an open access article licensed under the terms of the Creative Commons Attribution License (http://creativecommons.org/licenses/by/2.0) which permits unrestricted use, distribution and reproduction in any medium, provided the work is properly cited.

Veterinary World, EISSN: 2231-0916 production features were also analysed on the basis of various supplemented feed provided by the farmers. Attempt was also made to analyze the production cost of an egg and there by benefit-cost analysis. The study may help the farmers and planners to evaluate the backyard chicken rearing system in rural areas and to take suitable programme thereof.

\section{Materials and Methods}

Ethical approval: Adequate measures were taken viz. good transportation system during transportation of chickens, well ventilated houses, proper sanitary and hygienic measures and provision of sufficient water and run space etc. to minimize pain or discomfort in accordance with the International Animal Ethics Committee. The study was approved by the University level committee framed for such research. During the study, the researchers explained the objective and methodology of the study to all farmers.

Study area and chickens: Study was conducted on 60000 RIR chickens in the year 2010 to 2013 covering five different agroclimatic zones viz. terai, old alluvial, new alluvial, red and laterite and coastal in the state West Bengal, India. Chickens were reared by the 1500 experienced women farmers who were belong to 150 
Table-1: Ration formulated by the farmers for backyard rearing RIR chickens in different agro-climatic zones of West Bengal, India using local resources with its cost.

\begin{tabular}{|c|c|c|c|c|c|c|c|c|c|c|c|c|}
\hline \multirow{2}{*}{$\begin{array}{l}\text { Ingredients used } \\
\text { [(in } \mathrm{kg}) \text { per } 100 \mathrm{~kg} \text { of feed] }\end{array}$} & \multicolumn{6}{|c|}{ Various CP grades } & \multirow[t]{2}{*}{ Overall } & \multicolumn{5}{|c|}{ Agro-climatic zones } \\
\hline & ] 1 & 2 & 3 & 4 & 5 & 6 & & Terai & $\begin{array}{c}\text { New } \\
\text { Alluvial }\end{array}$ & $\begin{array}{c}\text { Red } \\
\text { Laterite }\end{array}$ & Old & Coastal \\
\hline 1. Unpolished rice & 0 & 1 & 1 & 1 & 1 & 1 & 1 & 0 & 1 & 2 & 1.5 & 0 \\
\hline 2. Wheat (broken) & 5 & 23 & 15 & 17 & 16 & 17 & 17 & 21 & 17.9 & 18.8 & 19 & 12 \\
\hline 3. Maize (broken) & 1 & 9.9 & 13 & 13 & 10 & 10.9 & 11 & 13 & 15 & 11 & 7 & 11 \\
\hline 4. Commercial layer feed & 0 & 5 & 9.9 & 14 & 16 & 14 & 11 & 14 & 11 & 11 & 5.2 & 12 \\
\hline 5. Rice (broken) & 49 & 31 & 26 & 24 & 23 & 18 & 26 & 21 & 24 & 22 & 31 & 29.8 \\
\hline 6. Rice bran & 11 & 8 & 8 & 7.9 & 11 & 17 & 9 & 9 & 8 & 11 & 7 & 10 \\
\hline 7. Boiled rice & 14 & 14 & 18 & 13 & 14 & 12 & 14.9 & 11 & 14 & 12 & 18 & 17 \\
\hline 8. Paddy & 14 & 5 & 7 & 8 & 8 & 9 & 8 & 10 & 7 & 9 & 9 & 7 \\
\hline 9. Fish & 0 & 0.1 & 0.1 & 0.1 & 0 & 0.1 & 0.1 & 0 & 0.1 & 0.2 & 0.3 & 0.2 \\
\hline 10. Snail & 6 & 3 & 2 & 2 & 1 & 1 & 2 & 1 & 2 & 3 & 2 & 1 \\
\hline Total & 100 & 100 & 100 & 100 & 100 & 100 & 100 & 100 & 100 & 100 & 100 & 100 \\
\hline Intake protein** & $0.69^{f}$ & $2.11^{\mathrm{e}}$ & $3.99^{d}$ & $6.23^{c}$ & $8.73^{b}$ & $11.31^{a}$ & 4.47 & $5.36^{a}$ & $3.37^{c}$ & $3.70^{\mathrm{C}}$ & $4.30^{b}$ & $4.95^{b}$ \\
\hline (gram/bird/day) & \pm 0.03 & \pm 0.05 & \pm 0.04 & \pm 0.07 & \pm 0.10 & \pm 0.23 & \pm 0.11 & \pm 0.23 & \pm 0.14 & \pm 0.26 & \pm 0.21 & \pm 0.28 \\
\hline Mixed ration provided & 27.80 & 38.13 & 49.91 & 60.23 & 70.58 & 86.50 & 51.07 & 46.25 & 31.93 & 43.29 & 58.57 & 48.40 \\
\hline (gram/bird) & \pm 5.12 & \pm 4.78 & \pm 8.04 & \pm 10.45 & \pm 7.21 & \pm 11.43 & \pm 8.78 & \pm 2.02 & \pm 1.09 & \pm 2.44 & \pm 1.97 & \pm 2.32 \\
\hline Green vegetables provided & 11.05 & 14.14 & 19.03 & 17.23 & 14.34 & 20.21 & 16.54 & 9.91 & 19.49 & 18.16 & 32.54 & 16.61 \\
\hline (gram/bird) & \pm 3.45 & \pm 3.74 & \pm 7.25 & \pm 6.41 & \pm 6.52 & \pm 5.42 & \pm 5.11 & \pm 0.75 & \pm 1.02 & \pm 1.57 & \pm 2.05 & \pm 1.33 \\
\hline Total amount of feed & 38.80 & 52.83 & 68.92 & 77.25 & 84.88 & 106.70 & 67.62 & 56.16 & 51.42 & 61.45 & 91.11 & 65.01 \\
\hline provided (gram / bird) & \pm 5.04 & \pm 4.32 & \pm 7.88 & \pm 9.41 & \pm 6.73 & \pm 9.42 & \pm 6.89 & \pm 2.13 & \pm 1.23 & \pm 2.84 & \pm 1.99 & \pm 2.43 \\
\hline Feed cost (Rs./Kg) & 5.72 & 5.93 & 5.69 & 6.52 & 7.16 & 7.11 & 6.08 & 7.83 & 6.03 & 6.67 & 5.49 & 7.38 \\
\hline Feed cost ${ }^{* *}$ (Rs./bird/day) & $\begin{array}{l}0.22^{d} \\
\pm 0.01\end{array}$ & $\begin{array}{l}0.31^{c d} \\
\pm 0.01\end{array}$ & $\begin{array}{l}0.39^{c} \\
\pm 0.01\end{array}$ & $\begin{array}{l}0.50^{\mathrm{b}} \\
\pm 0.02\end{array}$ & $\begin{array}{l}0.61^{b} \\
\pm 0.34\end{array}$ & $\begin{array}{l}0.76^{a} \\
+0.04\end{array}$ & $\begin{array}{c}0.41 \\
+0.02\end{array}$ & $\begin{array}{l}0.44^{b} \\
+0.02\end{array}$ & $\begin{array}{l}0.31^{c} \\
+0.01\end{array}$ & $0.41^{\mathrm{b}}$ & $0.50^{\mathrm{a}}$ & $0.48^{a}$ \\
\hline
\end{tabular}

** $\mathrm{P} \leq 0.01$ Means in the same row having common alphabet within various CP grades / agro-climatic zones does not differ significantly.

self help groups (SHGs). The area of the study was selected randomly within a zone and the SHGs were selected equal numbers in each zone on the basis of survey conducted exclusively for this study, which had early experience of backyard indigenous and upgraded chicken rearing.

Service and support provided: Each farmer was provided 40 RIR day-old chicks in two lots with uniform night shelter and brooding facilities. The chickens were maintained by the common health care management schedule at free range system in the backyard of the farmers. Initially all the farmers were also provided $1.39 \mathrm{~kg}$ chick mash having crude protein (CP) of $17.23 \%$ upto 10 weeks and $2.8 \mathrm{~kg}$ grower mash having CP of $12.32 \%$ for the period of $11-20$ weeks following the schedule as per Barua et al. [6]. Total cost of the initial feed was INR 119.71 per chicken. After 20 weeks, the chickens were provided variable types of supplemented feed produced by the farmers using local resources as farming practices. The ingredients used for preparing $100 \mathrm{~kg}$ feed and amount provided to each chicken with feed cost are presented in Table-1. Weekly egg production and other related records were collected from the farmers' register. The register was provided exclusively for this study before input supply and checked regularly.

Analysis of feed: $\mathrm{CP} \%$ is presented in the form of total protein intake per chicken per day and amount of supplemented feed provided to the chickens by the farmers. The $\mathrm{CP} \%$ of the feed was assessed following method AOAC 976.05 [7]. Depending upon CP intake on the basis of total quantity of protein provided from the supplemented feed was grouped into 6 types as CP grade 1-6 and ranked as 1, 2, 3, 4, 5 and 6 where protein intake was upto $1.00 \mathrm{gm} /$ chicken/day $(0.69 \pm 0.03)$ marked as 1, 1.01-3.00 gm/chicken/day $(2.11 \pm 0.05)$ marked as 2, 3.01-5.00 gm/chicken/day $(3.99 \pm 0.04)$ marked as 3, 5.01-8.00 gm/chicken/day $(6.23 \pm 0.07)$ marked as $4,8.01-10.00 \mathrm{gm} / \mathrm{chicken} /$ day $(8.73 \pm 0.10)$ marked as 5 and 10.01-15.00 gm/chicken/day (11.31 \pm $0.23)$ marked as 6 with an overall mean of $(4.47 \pm 0.11)$ gm CP intake per day per chicken (Table-1).

Statistical analysis: The mean and standard deviation of the egg production performance viz. age of puberty, weekly hen day, total egg produced and production period was statistically analyzed in respect to $\mathrm{CP}$ grade i.e. source of variance on the basis of farmers' record upto $18^{\text {th }}$ month age of chicken. Mean of all the characters were further compared with $\mathrm{CP}$ grade following one-way analysis of variance techniques along with Duncan's test at 5\% level of significance [8]. Main effect mean of CP grade if found significant, was displayed along with small alphabets where similar alphabets denote homogeneous means due to Duncan's test $(\mathrm{P}<0.05)$.

Considering the usual backyard farming practice, egg was considered as only source of income and all the produced eggs were considered as table egg for calculating benefit-cost analysis which was INR 3.88 as per farmers' record. Feed cost and cost of all other expenditures viz. health care management cost, electricity / fuel cost, other contingency expenditures was calculated from the farmers' record which was considered as 70:30 at any particular time. The benefit - cost ratio (B:C) was then calculated month wise from $5^{\text {th }}$ month onwards. 
Table-2: Egg production features of RIR chickens reared at backyard obtained by using initial commercial feed followed by various supplemented feed used in farming practices in different agro-climatic zones of West Bengal, India.

\begin{tabular}{|c|c|c|c|c|c|c|c|c|c|c|c|c|}
\hline \multirow[t]{2}{*}{ Parameter } & \multicolumn{6}{|c|}{ Various CP grades } & \multirow[t]{2}{*}{ Overall } & \multicolumn{5}{|c|}{ Agro-climatic zones } \\
\hline & 1 & 2 & 3 & 4 & 5 & 6 & & Terai & $\begin{array}{c}\text { New } \\
\text { Alluvial }\end{array}$ & $\begin{array}{c}\text { Red } \\
\text { Laterite }\end{array}$ & Old & Coastal \\
\hline ek) & $\begin{array}{l}24.23^{\mathrm{a}} \\
\pm 3.06\end{array}$ & $\begin{array}{l}24.57^{\mathrm{a}} \\
\pm 2.92\end{array}$ & $\begin{array}{c}23.08^{\mathrm{ab}} \\
\pm 2.32\end{array}$ & $\begin{array}{l}23.15^{\mathrm{ab}} \\
\pm 2.23\end{array}$ & $\begin{array}{c}23.49^{\mathrm{ab}} \\
\pm 3.28\end{array}$ & $\begin{array}{l}22.13^{\mathrm{b}} \\
\pm 2.80\end{array}$ & $\begin{array}{l}23.56 \\
\pm 2.69\end{array}$ & $\begin{array}{l}23.45^{\mathrm{b}} \\
\pm 1.96\end{array}$ & $\begin{array}{l}24.25^{\mathrm{c}} \\
\pm 2.27\end{array}$ & $\begin{array}{l}24.90^{\mathrm{d}} \\
\pm 2.96\end{array}$ & $\begin{array}{l}21.82^{\mathrm{a}} \\
\pm 2.80\end{array}$ & $\begin{array}{l}23.38^{\mathrm{b}} \\
\pm 2.34\end{array}$ \\
\hline day $^{* *}$ & $\begin{array}{c}3.17^{\mathrm{b}} \\
\pm 0.55\end{array}$ & $\begin{array}{l}3.18^{\mathrm{b}} \\
\pm 0.58\end{array}$ & $\begin{array}{l}3.23^{\mathrm{ab}} \\
\pm 0.42\end{array}$ & $\begin{array}{l}3.33^{\mathrm{ab}} \\
\pm 0.47\end{array}$ & $\begin{array}{l}3.20^{\mathrm{ab}} \\
\pm 0.46\end{array}$ & $\begin{array}{l}3.43^{\mathrm{ab}} \\
\pm 0.36\end{array}$ & $\begin{array}{r}3.24 \\
\pm 0.50\end{array}$ & $\begin{array}{l}3.24^{\mathrm{b}} \\
\pm 0.24\end{array}$ & $\begin{array}{l}3.16^{\mathrm{b}} \\
\pm 0.48\end{array}$ & & $\begin{array}{l}3.24^{\mathrm{b}} \\
\pm 0.45\end{array}$ & $\begin{array}{l}3.45^{a} \\
\pm 0.35\end{array}$ \\
\hline $\begin{array}{l}\text { Total egg produced }{ }^{* *} \\
\text { (No./chicken) }\end{array}$ & $\begin{array}{l}148.83^{\mathrm{ab}} \\
\pm 28.82\end{array}$ & $\begin{array}{l}138.41^{\mathrm{b}} \\
\pm 36.16\end{array}$ & $\begin{array}{l}152.69^{\mathrm{ab}} \\
\pm 28.89\end{array}$ & $\begin{array}{l}158.85^{\mathrm{ab}} \\
\pm 28.48\end{array}$ & $\begin{array}{c}153.76^{\mathrm{ab}} \\
\pm 26.84\end{array}$ & $\begin{array}{l}168.36^{\mathrm{a}} \\
\pm 24.87\end{array}$ & $\begin{array}{l}150.72 \\
\pm 31.99\end{array}$ & $\begin{array}{l}146.76^{\mathrm{b}} \\
\pm 31.43\end{array}$ & $\begin{array}{l}142.12^{\mathrm{b}} \\
\pm 34.20\end{array}$ & $\begin{array}{l}144.43^{\mathrm{b}} \\
\pm 36.92\end{array}$ & $\begin{array}{l}159.75^{a} \\
\pm 28.02\end{array}$ & $\begin{array}{l}{ }^{a} 160.56^{a} \\
\pm 23.12\end{array}$ \\
\hline $\begin{array}{l}\text { Production period }{ }^{* *} \\
\text { (week) }\end{array}$ & $\begin{array}{c}46.93^{\mathrm{ab}} \\
\pm 4.29\end{array}$ & $\begin{array}{l}43.44^{\mathrm{b}} \\
\pm 8.66\end{array}$ & $\begin{array}{c}47.25^{\mathrm{ab}} \\
\pm 6.31\end{array}$ & $\begin{array}{c}47.69^{\mathrm{ab}} \\
\pm 5.31\end{array}$ & $\begin{array}{l}47.94^{\mathrm{ab}} \\
\pm 5.09\end{array}$ & $\begin{array}{l}49.09^{\mathrm{a}} \\
\pm 4.48\end{array}$ & $\begin{array}{l}46.38 \\
\pm 6.88\end{array}$ & $\begin{array}{l}45.23^{\mathrm{b}} \\
\pm 7.88\end{array}$ & $\begin{array}{l}44.86^{\mathrm{b}} \\
\pm 8.49\end{array}$ & $\begin{array}{l}46.07^{\mathrm{b}} \\
\pm 6.26\end{array}$ & $\begin{array}{l}49.18^{\mathrm{a}} \\
\pm 4.61\end{array}$ & $\begin{array}{l}46.59^{\mathrm{b}} \\
\pm 5.64\end{array}$ \\
\hline
\end{tabular}

** $\mathrm{P} \leq 0.01$ Means in the same row having common alphabet within various CP grades / agro-climatic zones does not differ significantly.

Table-3: Age wise egg production performance of RIR reared at backyard in different agro-climatic zones of West Bengal, India using initial supplied feed followed by feed used in farming practices.

\begin{tabular}{|c|c|c|c|c|c|c|c|c|c|c|c|c|}
\hline \multirow{2}{*}{$\begin{array}{l}\text { Age of chicken } \\
\text { (week/month) }\end{array}$} & \multicolumn{6}{|c|}{ Various CP grades } & \multirow[t]{2}{*}{ Overall } & \multicolumn{5}{|c|}{ Agro-climatic zones } \\
\hline & 1 & 2 & 3 & 4 & 5 & 6 & & Terai & $\begin{array}{c}\text { New } \\
\text { Alluvial }\end{array}$ & $\begin{array}{c}\text { Red } \\
\text { Laterite }\end{array}$ & Old & Coastal \\
\hline $20 / 5$ & 0.07 & 0.04 & 0.07 & 0.10 & 0.00 & 0.41 & 0.08 & 0.07 & 0.06 & 0.08 & 0.55 & 0.12 \\
\hline $24 / 6$ & 3.36 & 3.22 & 3.64 & 2.98 & 2.39 & 5.43 & 3.36 & 1.90 & 1.01 & 1.32 & 7.19 & 2.98 \\
\hline $28 / 7$ & 13.60 & 14.06 & 14.51 & 12.65 & 12.52 & 16.49 & 13.81 & 10.51 & 8.71 & 7.29 & 22.81 & 12.15 \\
\hline $32 / 8$ & 28.36 & 29.75 & 30.04 & 27.48 & 27.17 & 31.25 & 29.05 & 24.54 & 22.85 & 19.00 & 41.55 & 25.66 \\
\hline $36 / 9$ & 45.61 & 45.71 & 47.10 & 44.42 & 45.08 & 49.79 & 45.97 & 41.03 & 39.52 & 34.58 & 58.98 & 42.59 \\
\hline $40 / 10$ & 64.20 & 62.83 & 64.81 & 61.05 & 63.92 & 67.75 & 63.36 & 57.86 & 56.54 & 50.18 & 75.85 & 60.73 \\
\hline 44 / 11 & 80.58 & 78.39 & 81.61 & 78.33 & 84.28 & 85.03 & 80.26 & 74.35 & 71.63 & 64.86 & 90.84 & 78.83 \\
\hline $48 / 12$ & 98.71 & 92.24 & 94.62 & 93.51 & 102.27 & 102.68 & 94.82 & 89.64 & 84.33 & 78.61 & 104.21 & 96.54 \\
\hline $52 / 13$ & 112.78 & 104.60 & 106.40 & 106.71 & 116.07 & 116.36 & 107.45 & 103.20 & 95.97 & 91.38 & 116.02 & 112.18 \\
\hline $56 / 14$ & 124.97 & 115.02 & 117.88 & 119.20 & 126.67 & 127.95 & 118.98 & 115.62 & 106.91 & 103.92 & 126.89 & 124.78 \\
\hline $60 / 15$ & 135.12 & 124.16 & 128.00 & 129.67 & 137.63 & 141.51 & 129.20 & 125.13 & 117.52 & 115.61 & 136.82 & 135.64 \\
\hline $64 / 16$ & 145.69 & 132.69 & 137.34 & 139.14 & 147.36 & 154.27 & 138.65 & 133.56 & 127.26 & 126.09 & 145.84 & 145.66 \\
\hline $68 / 17$ & 147.21 & 136.54 & 146.32 & 148.25 & 150.35 & 161.74 & 147.45 & 141.07 & 135.10 & 135.96 & 154.17 & 154.45 \\
\hline 72 / 18 & 148.83 & 138.41 & 152.69 & 158.85 & 153.76 & 168.36 & 150.72 & 146.74 & 142.19 & 144.63 & 159.72 & 160.61 \\
\hline
\end{tabular}

\section{Results}

Major egg production performances viz. age of maturity, average weekly hen day, total egg production and production period in different agro-climatic zones and on the basis of various supplemented feed provided by the farmers were presented in Table-2. It appeared that overall laying period had been started from the age of $23.56 \pm 2.69$ weeks (165 days). In the study it was also appeared that average weekly hen day was $3.24 \pm$ 0.50 and produced $150.72 \pm 31.99$ eggs per chicken per year within $46.38 \pm 6.88$ weeks laying period. The chickens reared under CP 1 and 2 graded feed also showed comparatively less hen day. On the contrary, the chickens reared under CP 6 graded feed showed earliest maturity, highest average weekly hen day (3.43 \pm 0.36 ) and maximum laying period (49.09 \pm 4.48 weeks) with highest egg production performance $(168.36 \pm 24.87$ eggs per bird per year). Agro-climatic zone comparison feature showed that early maturity $(21.82 \pm 2.80$ weeks $)$, highest egg production performance $(159.75 \pm 28.02$ eggs per bird per year) and maximum laying period (49.18 \pm 4.61 weeks) was happened in old alluvial zone, where coastal zone also showed highest egg production performance along with highest average weekly hen day $(3.45 \pm 0.35)$.

Age wise egg production performance under various CP graded feed and in different agro-climatic zones has been presented in Table- 3 .

Table-4 showed the benefit cost ratio $(B: C)$ in respect of egg production. It was appeared that profit started from $9^{\text {th }}$ month under CP grade 1 and 2 and in old alluvial zone, from $10^{\text {th }}$ month in overall and in all other $\mathrm{CP}$ graded feed except CP grade 6 and also in all other zones except red laterite zone. Profit started and continued in all graded feed as well as all agro-climatic zones of West Bengal including CP grade 6 and in red laterite zone from $11^{\text {th }}$ month onwards. It was also appeared that maximum profit and least production cost for producing an egg was occurred in CP grade 1 and in new alluvial zone; where least profit with maximum egg production cost was occurred in CP graded 6 and in terai and old alluvial zone. It was noticed that rate of feeding of aquatic snail was highest in CP grade 1 feed and decreased gradually in subsequent $\mathrm{CP}$ graded feed.

\section{Discussion}

The age of maturity of the present finding was corroborated with the age of maturity of Vanaraja and Gramapriya breed reared at backyard [9]. In overall study, the average weekly hen day and total egg produced per chicken per year was similar whereas profitable egg laying period was found to be higher than the previous report of Sonaiya et al. [10]. 
Table-4: Benefit-Cost analysis (B:C) of RIR chickens reared at backyard in different agro-climatic zones of West Bengal in respect of egg production.

\begin{tabular}{|c|c|c|c|c|c|c|c|c|c|c|c|c|c|}
\hline Week & Parameter & & & arious & grades & & & Overall & & Agro & -climatic & zones & \\
\hline (m & & 1 & 2 & 3 & 4 & 5 & 6 & & $\begin{array}{c}\text { Terai } \\
\text { Alluvial }\end{array}$ & $\begin{array}{c}\text { New } \\
\text { Laterite }\end{array}$ & Red & Old & onst \\
\hline (5th) & lef of Th o & (2) & $010-10-2$ & 0.29 & 0.00 & 0.00 & 155 & 0.29 & 27 & 0.23 & 0.31 & 2.14 & 0.47 \\
\hline & & 119.71 & & & & & & & & & & 119.71 & \\
\hline & $\mathrm{B}: \mathrm{C}$ & & & & & 0 & & & & 0. & & & \\
\hline (6th) & Value & g 13.07 & 12.50 & & & 9.27 & & 1306 & 7.391 & 3.93 & & & \\
\hline & Total c & 129.14 & 133.00 & 136.43 & 141.14 & 145.86 & 152.29 & 137.29 & 137.31 & 132.11 & 136.11 & 139.71 & 138.91 \\
\hline & $B: C$ & & 0.09 & & & & & & & & & 0.20 & \\
\hline 7th) & Value & 52.99 & 54.81 & $5656>$ & & & & & & & & & \\
\hline & Total & 138.57 & 146.29 & 153 & 16 & 172 & 184 & & 154 & 144 & & 159.71 & 158 \\
\hline & $B: C$ & & 0.37 & 0.3 & 0.3 & 0.2 & & & & & & 0.56 & \\
\hline 3th) & Value & g 11 & & & & & & & & & & & \\
\hline & Tote & 148. & 1 & & & & & & & & & & \\
\hline & $\mathrm{B}: \mathrm{C}$ & & & & & & & & & & & & \\
\hline & Val & & & & & & & & & & & & \\
\hline & Tot & 15 & 17 & & & & & & & & & & \\
\hline & $\mathrm{B}: \mathrm{C}$ & & & & & & & & & & & & \\
\hline & ) $\mathrm{Va}$ & $\mathrm{g} 2$ & & & & & & & & & & & \\
\hline & Tota & 166.86 & 186. & 2 & & & & & & & & & \\
\hline & $\mathrm{B}:$ & & & & & & & & & & & & \\
\hline 4 (11th) & $\mathrm{Va}$ & 3 & & & & & & & & & & & \\
\hline & & & & & & & & & & & & & \\
\hline & B: & & & & & & & & & & & & \\
\hline $8(12$ th $)$ & ) $\mathrm{Va}$ & $g 38$ & 35 & 3 & & & & & & & & & \\
\hline & & & & & & & & & & & & & \\
\hline & B: & & & & & & & & & & & & \\
\hline ) & ) Value & 943 & 407.92 & 41 & & & & & & & & & \\
\hline & & & & & & & & & & & & & \\
\hline & B: & & & & & & & & & & & & \\
\hline & ) Valu & g 487.3 & & & & & & & & & & & \\
\hline & & & & & & & & & & & & & \\
\hline & $\mathrm{B}:$ & & & & & & & & & & & & \\
\hline & ) Value & g 526.9 & & & & & & & & & & & \\
\hline & & & & & & & & & & & & & \\
\hline & $\mathrm{B}: \mathrm{C}$ & & 1.92 & & & & & & & & & & \\
\hline 1 & ) Value & g 568.16 & 517.43 & & & & & & & & & & \\
\hline & & 22 & & & & & & & & & & & \\
\hline & $\mathrm{B}:$ & & & & & & & & & & & & \\
\hline & ) Val & g 598.8 & 515 & & & & & & & & & & \\
\hline & & & & & & & & & & & & & \\
\hline & $\mathrm{B}:$ & & & & & & & & & & & & \\
\hline & ) $\mathrm{Va}$ & 62 & & & & & & & & & & & \\
\hline & & 242 & 292.43 & 337 & & 459 & 543 & $34 \varepsilon$ & & & & 379.71 & 369.31 \\
\hline & $\mathrm{B}:$ & & & & & & & & & & & & 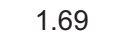 \\
\hline & ion $\mathrm{cc}$ & & 2.00 & & & 2 & 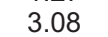 & & 0 & 1 & 2.30 & 2.38 & 2.30 \\
\hline
\end{tabular}

Significantly delayed onset of maturity (nearly 1 week) was observed to the birds reared under CP 1 and 2 grade feed and in both new alluvial and red and laterilte zones; but this finding was better than the earlier report [6] where age of maturity was observed at 37 weeks in RIR. This might be due to supplementation of good quality feed at the chicks and growing stage [11].

The chickens reared under CP 1 though showed less hen day but its egg production performance was similar with the other grade feed. Chickens reared under CP 2 grade feed was also showed comparatively less hen day might be due to less availability of protein of their feed [12]. Whereas, the chickens reared under CP 6 graded feed showed earliest maturity, highest average weekly hen day and maximum laying period which might be due to continuous supply of more protein containing feed contributing highest egg production performance. In various agro-climatic zones, comparatively low egg production performance was observed in terai, new alluvial and red and laterite zones. This might be due to less hen day average; as a result their total production period was reduced also. Old alluvial and coastal zone showed significantly higher egg production performance was probably due to supply of more quantity of feed to the chickens.

Overall egg production rate of the present study was higher than the earlier report of backyard RIR at $9^{\text {th }}$ week and comparable at $10^{\text {th }}$ week of the chickens reared at farm [13]. Result showed that though there was significant variation occurred in various grade feed cost, but no significant variation persisted in respect of total egg production, except production performance of CP 2 graded feed which may be due to total less production performance. Hence, it would be better to rear the chickens under that CP grade feed which had less production cost and more return i.e. more the value of benefit cost ratio (B:C).

Result of B:C showed that maximum profit as well as least production cost for producing an egg was occurred in $\mathrm{CP}$ grade 1 and in new alluvial zone, whereas, least profit with maximum egg production 
cost was in CP grade 6 and in terai and old alluvial zones. It might be due to availability of cheapest and good quality protein intake in CP grade 1 feed and in new alluvial zone by which the requirement of key indispensable amino acids were made available [14]. Hence, quantity of protein intake through supplemented feed by CP grade 1 and in new alluvial zone though was far below than the earlier observation [15] and also below than the other category of feed and zones respectively, yet produced equivalent quantities of eggs which made the backyard poultry farming more profitable when compared with other graded feed and zones. Further, higher egg production performance at backyard may not be an important criterion considering its benefitcost analysis.

\section{Conclusion}

Thus, it can be concluded that the basic egg production features along with production cost of an egg of backyard chickens under various level of supplemented feed has been standardized. The benefitcost analysis has also been calculated.

- $\quad$ So, it can be concluded that under scavenging system at backyard, profit will continue from 11 month onwards irrespective of protein supplementation available at various agro-climatic zones of West Bengal.

- In this system more protein as well as more quantity of supplemented feed may influence to produce more eggs but there is a scope of least profit due to higher egg production cost; rather supplementation of minimum protein through additional feed may causes more profit due to least production cost for producing an egg.

So, the rural poor farmers may follow this model for backyard chicken farming where a minimum support of initial feed upto pre-laying stage is to be provided.

\section{Authors' contributions}

PKD planned the study and supervised the entire work. PRG and SP drafted and reviewed the manuscript and monitored the work. BR analyzed the feed and reviewed the manuscript. DM analyzed the data and reviewed the manuscript. All authors read and approved the final manuscript.

\section{Acknowledgements}

The authors are extremely grateful to the Rahstriya Krishi Vikash Yojona under Government of India, West Bengal University of Animal \& Fishery Sciences for providing fund and Animal Resources Development Department, Government of West Bengal, India and three tier Panchayat system of West Bengal, India for the support to carry out the study smoothly. The authors are also thankful to the farmers who were eager to provide relevant data for carrying out this study.

\section{Competing interests}

The authors declare that they have no competing

\section{References}

1. Dana, N. and Ogole, B. (2002) Effect of scavenging on diet selection and performance of Rhode Island Red and Fayoumi breed of chicken offered a choice of energy and protein feeds, Trop. Anim. Hlth. Prod., 34(5): 417-429.

2. GoI. (2006) Livestock ownership across operational land holding classes in India, 2002-2003, NSS 59th round, Report No. 493 (59/18.1/1), Government of India, New Delhi.

3. Pica-Ciamarra, U. and Dhawan M. (2010) Small Scale Poultry Farming and Poverty Reduction in South Asia: From Good Practices to Good Policies in Bangladesh, Bhutan and India under South-Asia Pro-Poor Livestock Policy Programme, New Delhi, p1-49.

4. Das, K. (2008) Poultry Sector Review: India. Food and Agriculture Organization of the United Nations, Animal Production and Health Division, Emergency Centre for Transboundary Animal Diseases Socio Economics, Production and Biodiversity Unit. p1-52. Available from: ftp://ftp.fao.org/docrep/fao/011/ak069e/ak069e00.pdf Accessed on 27-01-2013.

5. Pica-Ciamarra, U. and Dhawan, M. (2009) A rapid rural appraisal of the family $\square$ based poultry distribution scheme of West Bengal. South Asia Pro Poor Livestock Policy Programme (SAPPLPP), a joint initiative of NDDB and FAO, Delhi, India. 2011. Available from: http:// sapplpp. org/ informationhub. Accessed on 30-06-2012.

6. Barua, A., Howlider, M. A. R. and Yoshimura, Y. (1998) A study on the performance of Fayoumi, Rhode Island Red and Fayoumi X Rhode Island Red chickens under rural condition of Bangladesh. Afr. J. Agric. Res., 11(6): 635-641.

7. AOAC. (2000) Official Methods of Analysis. Association of Official Analytical Chemists, $17^{\text {th }}$ edition, Arlington, VA. p18, 35, 146.

8. Duncan, D.B. (1955) Multiple range and multiple F tests. Biometrics, 11:1-42.

9. Niranjan, M., Sharma, R. P., Rajkumar, U., Reddy, B. L. N., Chatterjee, R. N. and Battacharya, T. K. (2008) Comparative evaluation of production performance in improved chicken varieties for backyard farming, Int. J. Poult. Sci., 7(11): 1128-1131.

10. Sonaiya, E. B., Branckaert, R. D. S. and Gueye, E. F. (2012) Research and development options for family poultry. INFPDE-CONFERENCE. Animal Production and Health Division, FAO. Available from: http://www.fao.org/ag/ againfo/themes/en/infpd/econf_scope.html Accessed on 2701-2013.

11. Perez-Bonilla, A., Jabbour, C., Frikha, M., Mirzaie, S., Garcia, J. and Mateos, G. G. (2012) Effect of crude protein and fat content of diet on productive performance and egg quality traits of brown egg-laying hens with different initial body weight. Poult. Sci., 91(6): 1400-1405.

12. Nager, R.G. (2006) The challenges of making eggs. Ardea., 94(3):323-346.

13. PDP. (2011) Rural Poultry. Poultry for meat chapter. Project Directorate on Poultry (ICAR), Rajendranagar, Hydrabad, Andhra Pradesh-500030, India. Published by $\mathrm{R} \mathrm{N}$ Chatterjee. Annual Report - 2010-11, p51-52.

14. Perez-Bonilla, A., Jabbour, C., Frikha, M., Mirzaie, S., Garcia, J. and Mateos, G. G. (2012) Effect of crude protein and fat content of diet on productive performance and egg quality traits of brown egg-laying hens with different initial body weight. Poult. Sci., 91(6): 1400-1405.

15. Kingori, A. M., Tuitoek, J. K., Muiruri, H. K., Wachira, A. M. and Birech, E. K. (2007) Protein intake of growing indigenous chickens on free-range and their response to supplementation. Int. J. Poult. Sci., 6(9): 617-621. interests.

$* * * * * * * *$ 